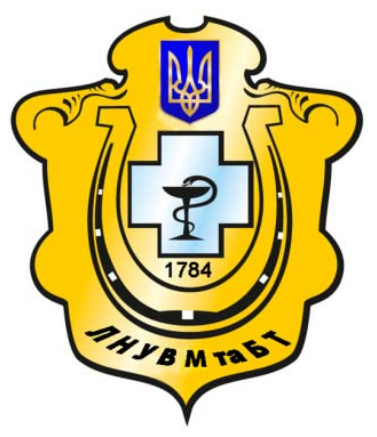

Науковий вісник Львівського національного університету ветеринарної медицини та біотехнологій імені С.3. Гжицького

Scientific Messenger of Lviv National University of Veterinary Medicine and Biotechnologies named after S.Z. Gzhytskyj

doi:10.15421/nvlvet7615

ISSN 2519-2701 print

ISSN 2518-1327 online

http://nvlvet.com.ua/

\title{
Особливості розвитку м'ясного птахівництва в сільськогосподарських підприємствах України
}

\author{
Р.М. Минів, І.В. Вороний \\ muniv@ukr.net \\ Львівський наиіональний університет ветеринарної медицини та біотехнологій імені С.З. Гжицького, \\ вул. Пекарська, 50, м. Львів, 79010, Україна
}

За останні роки в сільськогосподарських підприємствах галузі птахівництва спостерігається зростання поголів'я птичі й виробництва м'яса бройлерів. Головною причиною цъього розвитку є швидке виробнищтво і добра його окупність. $B$ Україні щзорічно вводяться у дію або реконструюються птахофабрики на найвищому технологічному рівні, щьо забезпечує постійне зростання поголів'я птииі, яке у 2016 р. склало 112008,7 тис. голів. За січень-жовтень 2016 року в Україні було вироблено 1846,7 тис. тонн м'яса всіх видів (у забійній вазі) всіма категоріями господарств. Щодо показника минулого року виробництво підвищилося на 0,8\% (+14,1 тис. тонн). Сільгосппідприємства виробили 1236,8 тис.тонн, щяо більше ніэ за аналогічний період 2015 року на 2,8\% (+34,0 тис. тонн). Виробництво м'яса птиці 2016 року складе 1,165 млн тонн у забійній вазі. Це на 3\% більше, ніж минулого. 920 тис. тонн із иуього об'єму вироблять промислові підприємства. За січеньжовтень 2016 року сільськогосподарськими підприємствами Украйни було реалізовано на забій 1084,3 тис. тонн (живоі ваги) м'яса птиці всіх видів. 3 них реалізовано бройлерів 1030,0 тис. тонн, щьо на 2,6\% (+25,8 тис. тонн) більше ніж минулого року. Середні иіни реалізачії 1 и живої маси птиці впродовж 2016 р. коливалися $і$ значною мірою залежали від строків продажу та каналів реалізаџії. Різниця між максимальною (травень - 39,27 грн/кг) і мінімальною (лютий 30,07 грн/кг); середньою за 2016 рік ичіною одиниці живої маси птииі в Украйні становила 4,79 грн/кг.

Стан розвитку галузі птахівництва в Украйні свідчить про те, щзо в результаті інвестування відбулося швидке збільшення обсягів виробництва м'яса птиці і при збереженні темпів зростання об'ємів виробництва в найближчі роки буде повністю насичений внутрішній ринок $і$ з 'явиться можливість експортування продукиії птахівництва в інші крайни.

Ключові слова: птахівництво, сільськогосподарські підприємства, поголів'я птиці, м'ясо птиці.

\section{Особенности развития мясного птицеводства в сельскохозяйственных предприятиях Украины}

\author{
Р.М. Мынив, И.В. Вороный \\ muniv@ukr.net
}

\begin{abstract}
Львовский национальный университет ветеринарной медицины и биотехнологий имени С.3. Гжицкого, ул. Пекарская, 50, г. Львов, 79010, Украина
\end{abstract}

\begin{abstract}
За последние годы в сельскохозяйственных предприятиях отрасли птицеводства наблюдается рост поголовья птицы и производства мяса бройлеров. Главной причиной этого развития является быстрое производство и хорошая его окупаемость. В Украине ежегодно вводятся в действие или реконструируютсях птицефабрики на самом высоком технологическом уровне, обеспечивающем постоянный рост поголовья птицы, которое в 2016 составило 112008,7 тыс. голов. За январь-октябрь 2016 года в Украине было произведено 1846,7 тыс. тонн мяса птицы всех видов (в убойном весе) всеми категориями хозяйств. Относительно показателя прошлого года производство повысилось на 0,8\% $(+14,1$ тыс. Тонн). Сельхозпредприятия произвели 1236,8 тыс. тонн, что выле показателя за аналогичный период 2015 году на 2,8\% (+34,0 тыс. тонн). Производство мяса птицы 2016 году составит 1165000 тонн в убойном весе. Это на 3\% больше, чем в проилом году, 920 тыс. тонн из этого объема выработают промышленные предприятия. За январь-октябрь 2016 года сельскохозяйственными предприятиями Украины было реализовано на забой 1084,3 тыс. тонн (живого веса) мяса птицы всех видов. Из нее реализовано бройлеров 1030,0 тыс.тонн, что на 2,6\% (+25,8 тысс.тонн) выше показателя прошлого года.
\end{abstract}

Citation:

Muniv, R.M., Voronuy, I.V. (2017). Features of development of the meat poultry farming in the agricultural enterprises of Ukraine. Scientific Messenger LNUVMBT named after S.Z. Gzhytskyj, 19(76), 77-81. 
Средние ичены реализации 1 и живой массы птицы в течение 2016 года колебались и в значительной степени зависели от сроков продажи и каналов реализации. Разница между максимальной (май - 39,27 грн/кг) и минимальной (февраль 30,07 грн/кг); средней за 2016 год иеной единиць живой массы птиць в Украине составляла 4,79 грн/кг.

Состояние развития отрасли птицеводства в Украине свидетельствует о том, что в результате инвестирования произошло быстрое увеличение объемов производства мяса птицы и при сохранении темпов роста объемов производства в ближайшие годы будет полностью насыщеен внутренний рынок и появится возможность экспорта продукиии птицеводства в другие странь.

Ключевые слова: птицеводство, сельскохозяйственные предприятия, поголовье птицы, мясо птицы.

\title{
Features of development of the meat poultry farming in the agricultural enterprises of Ukraine
}

\author{
R.M. Muniv, I.V. Voronuy \\ muniv@ukr.net \\ Lviv National University of Veterinary Medicine and Biotechnologies named after S.Z. Gzhytskyi, \\ Pekarska Str. 50, Lviv, 79010, Ukraine
}

In the last few years in the agricultural enterprises of poultry industry there is growth of poultry heads and chicken broilers meat production. Main reason of this development is a rapid production and good his recoupment. In Ukraine annually put in an operation or poultry factories are reconstructed at the greatest technological level, which provides permanent growth of poultry population, which in 2016 was 112008.7 ths. heads. During January-October 2016 in Ukraine 1846.7 thousands of tons of all kinds of meat (in for slaughter weight) were produced by all categories of economies. In relation to an index last year a production rose on $0.8 \%$ (+14.1 thousand of tons). Agricultural enterprises produced 1236.8 ths.t, that higher index for analogical period of 2015 on $2.8 \%$ (+ 34.0 ths.t). The production of poultry meat in 2016 will be made by 1.165 million tons in for slaughter weight. It on 3\% more than in the past year. 920 thousand tons from this volume will produced in industrial farms.

On January-October 2016 by the agricultural enterprises of Ukraine it was realized on a backwall 1084.3 thousands of tons (living weight) of all kinds poultry meat. From it is realized broilers of 1030.0 ths.t, that on $2.6 \%(+25.8$ ths.t) higher index last year. Average costs of realization $100 \mathrm{~kg}$ of living mass of poultry during 2016 hesitated and to a great extent depended on the terms of sale and ductings of realization. Difference between maximal (May is $39.27 \mathrm{UaH} / \mathrm{kg}$ ) and minimum (February is $30.07 \mathrm{UaH} / \mathrm{kg}$ ); $4.79 \mathrm{UaH} / \mathrm{kg}$ is the average cost of living mass of poultry in Ukraine during 2016 year.

Development of the poultry farming industry status in Ukraine testifies that as a result of investing and rapid increase of poultry meat production volumes took place at the maintenance rates of growth production and volumes in the nearest years an internal market will be fully saturated and possibility of exportation the poultry farming products will appear in other countries.

Key words: poultry farming, agricultural enterprises, poultry heads, poultry meat.

\section{Вступ}

На даний момент серед виробників продукції птахівництва спостерігається тенденція зростання виробництва. Саме птахопереробна галузь та птахівництво є ключовими в промисловості України з досить високою ефективністю, оскільки забезпечують населення цінним м'ясом і яйцями. Важливу роль відіграє зростання виробництва за рахунок якісних методів й технологій в даних галузях та задоволення потреб як внутрішнього, так і зовнішніх ринків.

Україна має достатньо сприятливе середовище для розвитку промислового птахівництва як для задоволення потреб внутрішнього, так і зовнішнього споживача. Саме ця галузь на даний момент динамічно розвивається i не вимагає значної підтримки 3 боку держави. Основними чинниками розвитку даної галузі $є$ стабільність процесу купівліпродажу, а також встановлення такого рівця цін, який би задовольняв суб'єктів ринку (Batiuk and Myniv, 2008; Myniv and Datsko, 2015; Myniv, 2015).

\section{Матеріал і методи досліджень}

Дослідженням основних напрямів розвитку птахівничої галузі займалися ряд вітчизняних учених, $\begin{array}{lll}\text { серед яких } & \text { В.П. Бородай, І.Г. Кириленко, }\end{array}$
Б.А. Мельник, В.В. Прядко, Ф.О. Ярошенко та інші. Б.А. Мельник займався дослідженням основних тенденцій розвитку світового м'ясного птахівництва. Ф.О Ярошенко розглядав напрями розвитку птахівництва в умовах ринкових відносин. Проте, незважаючи на значну кількість публікацій та їх наукову значущість в сучасних умовах господарювання, ринок продукції м'ясного птахівництва потребує постійного й детального дослідження. Оскільки птахівничі сільськогосподарські підприємства розвиваються досить швидкими темпами, тому потребують постійної уваги та аналізу тенденцій їх розвитку під впливом глобалізаційних змін.

Mema cmammi. Узагальнення особливостей розвитку м'ясного птахівництва в сільськогосподарських підприємствах України.

\section{Результати та їх обговорення}

Завдяки державній підтримці сільськогосподарських підприємств галузі птахівництва за останній період спостерігається зростання поголів'я птиці. В основному секторі птахівництва виробництві м'яса бройлерів зараз відбувається процес поглинань та перерозподілу ринку. Насамперед головною причиною цього розвитку $\epsilon$ 
швидке виробництво i добра його окупність. Незважаючи на велику поточну виробничу концентрацію (у десяти найбільших підприємствах перебуває майже $45 \%$ усього поголів'я птиці), продовжують утворюватися нові великі підприємства.

Починаючи 32000 р. птахівництво України в сільськогосподарських підприємствах демонструє активний розвиток. Щорічно вводяться у дію або реконструюються птахофабрики на найвищому технологічному рівні, що забезпечує постійне зростання поголів'я птиці, яке у 2016 р. склало 112008,7 тис. голів (рис. 1).

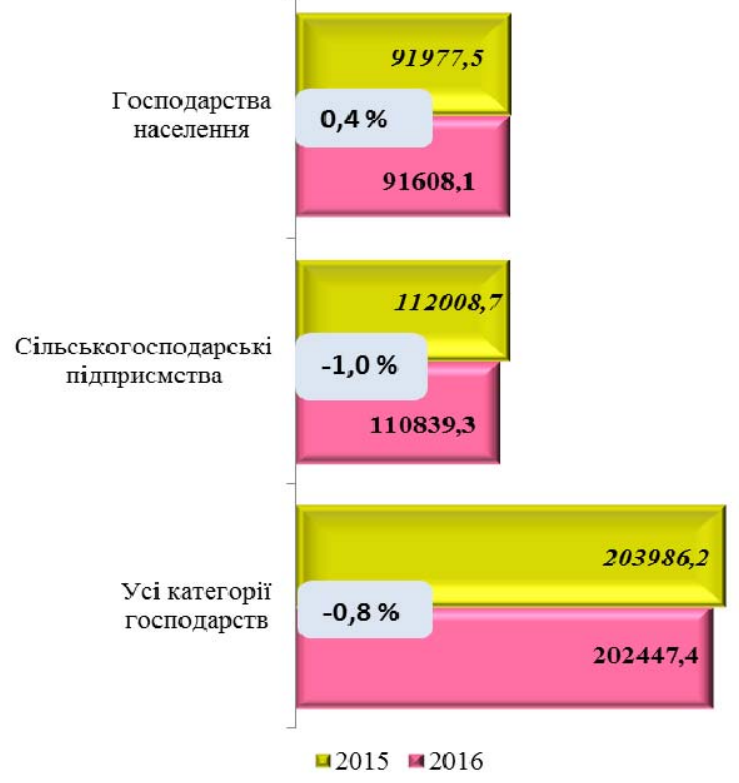

Рис. 1. Поголівя птиці в Україні за категоріями господарств, тис. голів

За січень-жовтень 2016 року в Україні було вироблено 1846,7 тис. тонн м'яса всіх видів (у забійній вазі) всіма категоріями господарств. Щодо показника минулого року виробництво підвищилося на 0,8\% (+14,1 тис. тонн). Сільгосппідприємства виробили 1236,8 тис. тонн, що більше за аналогічний період 2015 року на $2,8 \%$ (+34,0 тис. тонн) (рис. 2).

За даними Асоціації «Союз птахівників України» (СПУ), виробництво м'яса птиці 2016 року складе 1,165 млн тонн у забійній вазі. Це на 3\% більше, ніж минулого, 920 тис. тонн із цього об'єму вироблять промислові підприємства

Вітчизняні птахівники відчули складнощі ще на початку року через часткову відміну спеціального режиму ПДВ. Крім того, у структурі собівартості курятини великий відсоток займає імпорт (племінні ресурси, ветеринарні препарати, вітаміни, премікси, обладнання, запасні частини), а через девальвацію гривні в останні два роки імпортна складова зросла 3 15 до 40 відсотків. Подорожчали й комбікорми, які в структурі собівартості продукції птахівництва займають $65-70 \%$.

За січень-жовтень 2016 року сільськогосподарськими підприємствами України було реалізовано на забій 1084,3 тис. тонн (живої ваги) м'яса птиці всіх видів. Щодо показника минулого року обсяг реалізованої на забій птиці склав 103,3\%
(+34,7 тис. тонн). 3 неї реалізовано бройлерів 1030,0 тис. тонн, що на 2,6\% (+25,8 тис. тонн) вище за показники минулого року (рис. 3).

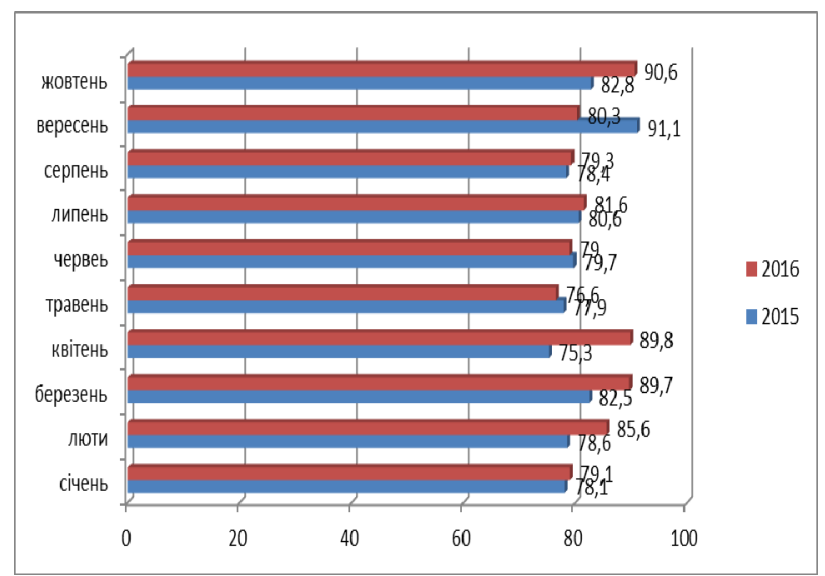

Рис. 2. Виробництво м'яса птиці в сільськогосподарських підприсмствах України, тис. тонн

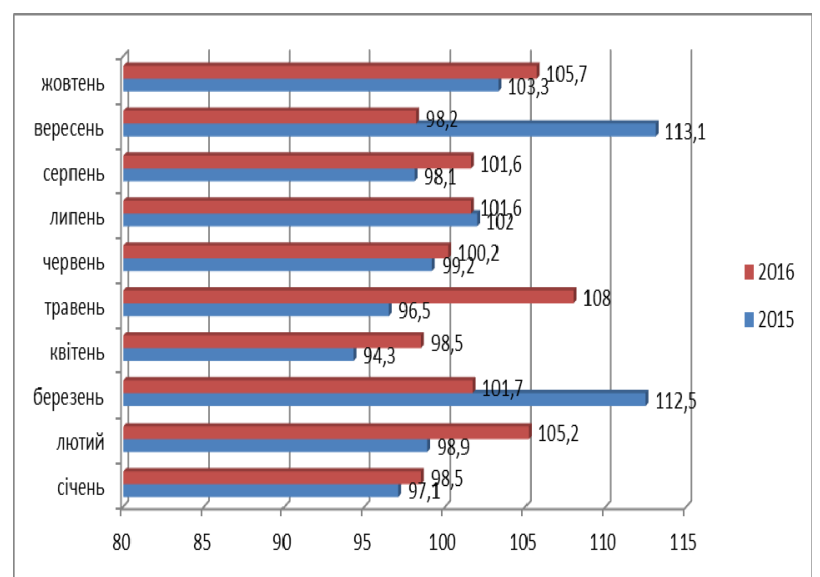

Рис. 3. Обсяги реалізації бройлерів на забі в сільськогосподарських підприємствах в живій мaci, тис. тонн

Лідерами за обсягами реалізованих на забій бройлерів $є$ такі області: Вінницька - 301,6 тис. тонн, Черкаська - 285,2 тис. тонн, Дніпропетровська 178,9 тис. тонн, Київська - 98,7 тис. тонн, Волинська - 69,4 тис. тонн, Львівська - 32,6 тис. тонн, Харківська - 24,2 тис.тонн, Рівненська - 12,3 тис. тонн і Хмельницька $-8,1$ тис. тонн.

Внутрішні ціни на м'ясо птиці в Україні коливаються, передусім, під впливом факторів витрат на виробництво, особливо на корми, напрямів реалізації й сезонності виробництва. Середні ціни реалізації 1 ц живої маси птиці впродовж 2016 р. коливалися i значною мірою залежали від строків продажу та каналів реалізації. Різниця між максимальною (травень - 39,27 грн/кг) і мінімальною (лютий - 30,07 грн/кг); середньою за 2016 р. ціною одиниці живої маси птиці в Україні становила 4,79 грн/кг (рис.4). 


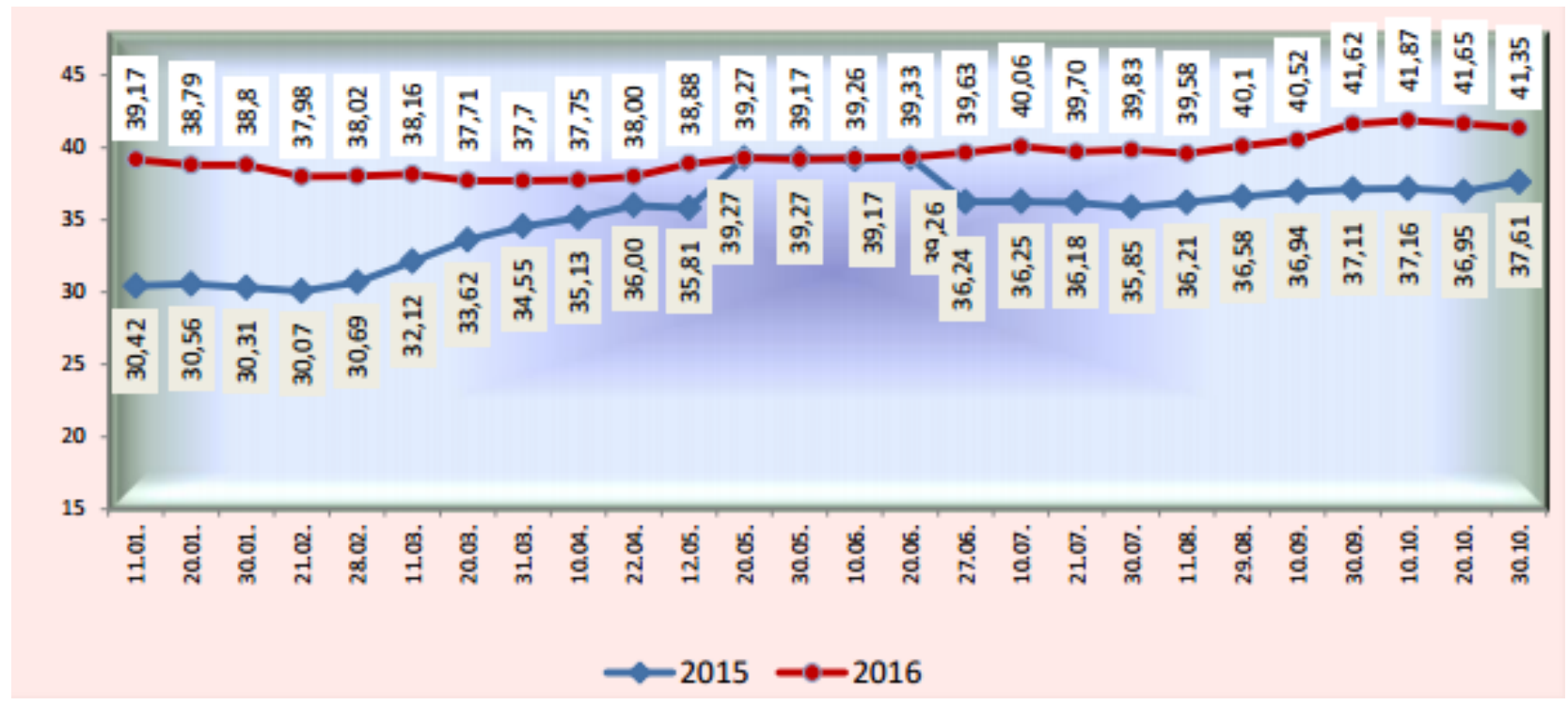

Рис. 4. Динаміка середніх споживчих цін на тушу курки в Україні, грн/кг

Цінові коливання на ринку м'яса птиці пов'язані лише з економічними та ринковими факторами і не залежать від запровадження пілотного проекту щодо ціноутворення на товари і послуги у сфері виробництва та реалізації продовольчих товарів - фактично 3 моменту його дії відпускні та споживчі ціни на м'ясо птиці лише зменшуються!

Ціни на продукцію птахівництва в Україні прив'язані до купівельної спроможності населення. А вона була і залишається низькою. Так, за даними Асоціації «Союз птахівників України», споживання м'яса птиці у 2016 році зменшилось до 24,2 кг на одну особу.

Останнім часом в Україні споживання населенням м'яса птиці перевищило рівень його споживання у країнах Європейського Союзу, адже український ринок насичений цим видом м'яса. Тому птахівництво активно розвиватиметься за рахунок нарощування обсягів експорту. Зростанню бройлерного виробництва сприяли прямі державні дотації, а з іншого боку незадовільне становище інших галузей м'ясного тваринництва та бажання українських виробників наситити внутрішній ринок вітчизняною продукцією.

За інформацією СПУ, у поточному році Україна поставить рекорд з експорту м'яса птиці. За 11 місяців вітчизняні виробники продали за кордон 224 тис. тонн цієї продукції, що перевищує показник за весь 2015 рік на 68\%. У вартісному вираженні експорт м'яса птиці за вказаний період 2016 року приніс 271,7 млн доларів проти 226,9 млн дол. у 2015 році. Частка ЄС у структурі експорту цієї продукції з України в січні-листопаді 2016 року склала 16\%, а за весь 2015 рік - 17\%. За даними ДФС, за 11 місяців 2016 року найбільше у вартісному вираженні експортували до Іраку - 74,5 млн дол., Нідерландів 32,1 млн доларів та Єгипту - 30,5 млн дол.

Стан розвитку галузі птахівництва в Україні свідчить про те, що в результаті інвестування відбулося швидке збільшення обсягів виробництва м'яса птиці і при збереженні темпів зростання об'ємів виробництва в найближчі роки буде повністю насичений внутрішній ринок і з'явиться можливість експортування продукції птахівництва в інші країни.

Птахівництво є одним з основних споживачів кормів: на потреби галузі у світі використовується 38\% всього вирощеного і виробленого промисловістю корму. В основі збільшення обсягів виробництва м'яса птиці має лежати нормована годівля: птиця повинна отримувати всі необхідні поживні, енергетичні та біологічно активні речовини з певною кількістю корму. Передусім це стосується курей м'ясних і м'ясо-яєчних порід. При цьому особливої гостроти набуває проблема доброякісності корму. Це обумовлено як появою значної кількості фальсифікованих кормів, так і зростанням вимог до якості продуктів харчування. Європейська система контролю якості НАССП (аналіз небезпечних чинників і контрольні критичні точки) передбачає контроль та зниження ризиків на всьому ланцюжку виробництва, починаючи 3 поля і закінчуючи переробкою та зберіганням продукції.

\section{Висновки}

Подальший розвиток українських сільськогосподарських птахівничих підприємств напряму залежатиме від розвитку експортних можливостей галузі. Відкриття ринку ЄС стало б найбільшим визнанням і можливістю для вітчизняних товаровиробників. Однак стримувальними факторами на шляху до європейських ринків є неготовність більшості господарств до проходження сертифікації контрольними органами країн ЄС, висока собівартість українського виробництва порівняно з європейським, високі кредитні банківські ставки та незначна підтримка 3 боку нашої держави порівняно з конкурентами з Євросоюзу.

Необхідно диверсифікувати ризики за рахунок розширення географії експортних поставок. Перспективними є ринки Азії та Близького Сходу. Інвестицій у нарощення потужностей чекати не варто - обігові 
кошти вкладатимуть в удосконалення технологій i, зменшення собівартості з метою подальшої конкурентоздатності. Поки що українські сільськогосподарські птахівничі підприємства переходять у стадію очікування, коли їх подальший розвиток напряму залежатиме від політичної та економічної ситуації в країні, зваженої роботи профільних міністерств й уряду в цілому. Нагальними проблемами для вирішення є стабілізація фіскальної політики, курсів валют, повернення ПДВ, гарантування незмінності чинної системи оподаткування господарств за єдиним податком тощо.

\section{Бібліографічні посилання}

Batiuk, B.B., Myniv, R.M. (2008). Funktsionuvannia ta rozvytok ptakhivnychykh pidpryiemstv: orhanizatsiino-ekonomichni zasady: [monohr.]. Lviv: Liha-Pres (in Ukrainian).

Myniv, R.M., Datsko, O.B. (2015). Efektyvnist silskohospodarskykh pidpryiemstv miasoproduktovoho pidkompleksu: teoriia, metodolohiia, praktyka: [monohr.]. Lviv: Spolom (in Ukrainian).

Myniv, R.M. (2015). Brendynh ptakhivnychykh pidpryiemstv. Naukovyi visnyk LNUVM ta BT imeni S.Z. Hzhytskoho. 17, 1(61), 238-244 (in Ukrainian).

Стаття надійшла до редакиії 11.03.2017 